\title{
Dissolved inorganic nitrogen uptake by intertidal microphytobenthos: nutrient concentrations, light availability and migration
}

\author{
Sorcha Ní Longphuirt ${ }^{1}$, Jae-Hyun Lim ${ }^{1}$, Aude Leynaert ${ }^{2}$, Pascal Claquin ${ }^{3}$, \\ Eun-Jung Choy ${ }^{4}$, Chang-Keun Kang ${ }^{4}$, Soonmo An $^{1, *}$ \\ ${ }^{1}$ Coastal Environmental System School, Pusan National University, 30 Jangjeon-dong, Geumjeong-gu, Busan 609-735, \\ South Korea \\ ${ }^{2}$ LEMAR, Laboratoire des Sciences de l'Environnement Marin, UMR 6539 CNRS, Institut Universitaire Européen de la Mer, \\ Technopôle Brest-Iroise, 29280 Plouzané, France \\ ${ }^{3}$ Laboratoire de Biologie et Biotechnologies Marines, UMR100 M IFREMER/UCBN PE2M, \\ Université de Caen Basse-Normandie, 14032 Caen cedex, France \\ ${ }^{4}$ Department of Biology, Pusan National University, Jangjeon-dong, Geumjeong-gu, Busan 609-735, South Korea
}

\begin{abstract}
The importance of intertidal flats as areas of nitrogen filtering has become increasingly apparent in recent times. To understand fully the cycling of this nutrient in these areas of high metabolic activity, it is necessary to elucidate the influence of microphytobenthos (MPB) on stocks of ammonium and nitrate in surface areas. In this study, we aimed to quantify nitrogen uptake and relate it to the in situ concentrations and environmental conditions to which MPB are exposed. In an estuarine system on the Korean Peninsula, we conducted kinetic experiments using ${ }^{15} \mathrm{~N}$ stable isotopes and core sampling over the tidal cycle to determine the temporal evolution of porewater nutrient concentrations and the migration of MPB. The results revealed a range of $K_{\mathrm{s}}$ values between 1.5 and 11.8 $\mu \mathrm{mol} \mathrm{l} \mathrm{l}^{-1}$ for ammonium and $19.2 \mu \mathrm{mol} \mathrm{l}^{-1}$ for nitrate. Thus MPB communities vary their affinity for dissolved inorganic nitrogen (DIN), which may be related to the substrate conditions to which they are exposed. Uptake of ammonium under experimentally darkened or natural night conditions was, on average, $50 \%$ lower than during light periods. The range of porewater DIN concentrations was large and appeared to be primarily determined by tidal influences. This oscillation, coupled to the vertical migration of the MPB in sediments, is likely to have a substantial effect on uptake over the short term (hours). The results indicate that, contrary to our conceptual model, the MPB largely incorporates DIN at the sediment surface during low tide periods when ammonium concentrations are at their highest. As a result, our representation of the MPB in coastal and estuarine models needs to be reassessed.
\end{abstract}

KEY WORDS: Nitrogen $\cdot$ Kinetic $\cdot$ Microphytobenthos $\cdot$ Porewater $\cdot{ }^{15} \mathrm{~N}$ stable isotope

\section{INTRODUCTION}

Microphytobenthos (MPB) communities are recognized as important primary producers in shallow coastal and estuarine ecosystems (Cahoon 1999, Underwood \& Kromkamp 1999). Their distinctive algal mats dominate a range of habitats stretching from beyond the highest intertidal mudflat regions to the benthos of all aquatic areas where light availability allows for photosynthesis. It is therefore not surprising that they are an increasingly important component of nutrient cycling studies and ecological models (Blackford 2002, Robson et al. 2008) of shallow coastal zones.

The first step in ensuring a correct representation of MPB is to directly define and quantify their functioning through experimentation. Certain aspects of MPB ecology have been comprehensively characterized, e.g. primary production (Underwood \& Kromkamp 1999, Serôdio \& Catarino 2000), vertical migration in intertidal (Palmer \& Round 1965, Underwood et al. 2005) and subtidal regions (Ní Longphuirt et al. 2006), and their resuspension during tidal flooding (Lucas et al. 
2000). However, despite the extensive literature available, very little experimentation has been carried out on the direct uptake of dissolved inorganic nutrients by in situ populations (Thornton et al. 1999, Leynaert et al. 2009), a process which is routinely represented in modelling and nutrient budget studies.

MPB activity has been shown to have a close relationship with coupled bacterial nitrification-denitrification processes (Sundbäck \& Miles 2000, Risgaard-Peterson et al. 2004). Rates of these bacterial processes, which remove nitrogen as $\mathrm{N}_{2}$ gas from coastal regions, rely on the availability of both nitrate and ammonium either from the overlying-water or from pore-water. Microphytobenthos, due to their direct uptake of ammonium and nitrate, reduce the availability of these ions for nitrifying and denitrifying bacteria, respectively (Risgaard-Peterson 2003, RisgaardPeterson et al. 2004). A direct quantification of dissolved inorganic nitrogen (DIN) assimilation rates would allow us to precisely determine their influence on these coupled processes and hence the overall cycling and retention of nitrogen in coastal sediments.

Nutrient concentrations can differ by one order of magnitude between the sediment-water interface and subsurface sediments (Sakamaki et al. 2006, Leynaert et al. 2009). Added to this vertical change in substrate availability, concentrations of ammonium and nitrate in intertidal sediments can oscillate greatly between submersion and emersion periods (Kuwae et al. 2003, Sakamaki et al. 2006). The MPB can therefore be subjected to large nutrient concentration fluctuations, firstly through their vertical migration into the sediment (Palmer \& Round 1965) and secondly as a result of the influences of tidal cycles. The uptake of DIN by the MPB will in turn oscillate over these migratory and tidal cycles due to the direct influence of substrate concentrations on uptake processes.

The objectives of this study were therefore (1) to quantify uptake kinetic of nitrate and ammonium by intertidal microphytobenthos, (2) to quantify ammonium uptake over the diurnal period, and (3) to examine the relationship between assimilation rates and in situ porewater concentrations taking into consideration vertical migration of microphytobenthos within the sediment and temporal changes in environmental conditions (nutrient concentrations, light availability) through the tidal cycle.

\section{MATERIAL AND METHODS}

Study site. The Nakdong River Estuary $\left(35^{\circ} 05^{\prime} \mathrm{N}\right.$, $128^{\circ} 55^{\prime} \mathrm{E}$ ) is located on the southeastern tip of the Korean peninsula (Fig. 1). It is fed by the Nakdong River, which has a large catchment area $\left(23817 \mathrm{~km}^{2}\right)$. In 1987 a large estuarine barrage was constructed at the mouth of the river and now regulates water discharge. As a result, the intertidal flats have expanded up to an area about $40 \mathrm{~km}^{2}$. The flats are protected by sand dunes that run parallel to the coastline. The surface sediment is composed mostly of muddy sand (sand $\leq \sim 90 \%$ and mean grain size of 2.6 to $3.9 \varphi$; Choy et al. 2008).

Experimental approach. Sampling was conducted over a 2 d period in August 2007 to determine the range of environmental factors (temperature, light, salinity, nutrient concentration and tidal currents) to which the MPB were exposed during diurnal and tidal cycles. Concurrently, the migration of the MPB was followed through a study of the concentrations of chl a (chlorophyll $a$, considered a proxy for the biomass) within the sediment over a depth range of $2 \mathrm{~cm}$. Following this, MPB ammonium uptake kinetics were assessed using the ${ }^{15} \mathrm{~N}$ stable isotope technique on cells extracted from the sediment at the site. Additionally, this uptake was studied over the diurnal cycle. Concurrent experiments on nitrate kinetics and diurnal uptake were also undertaken, but unfortunately

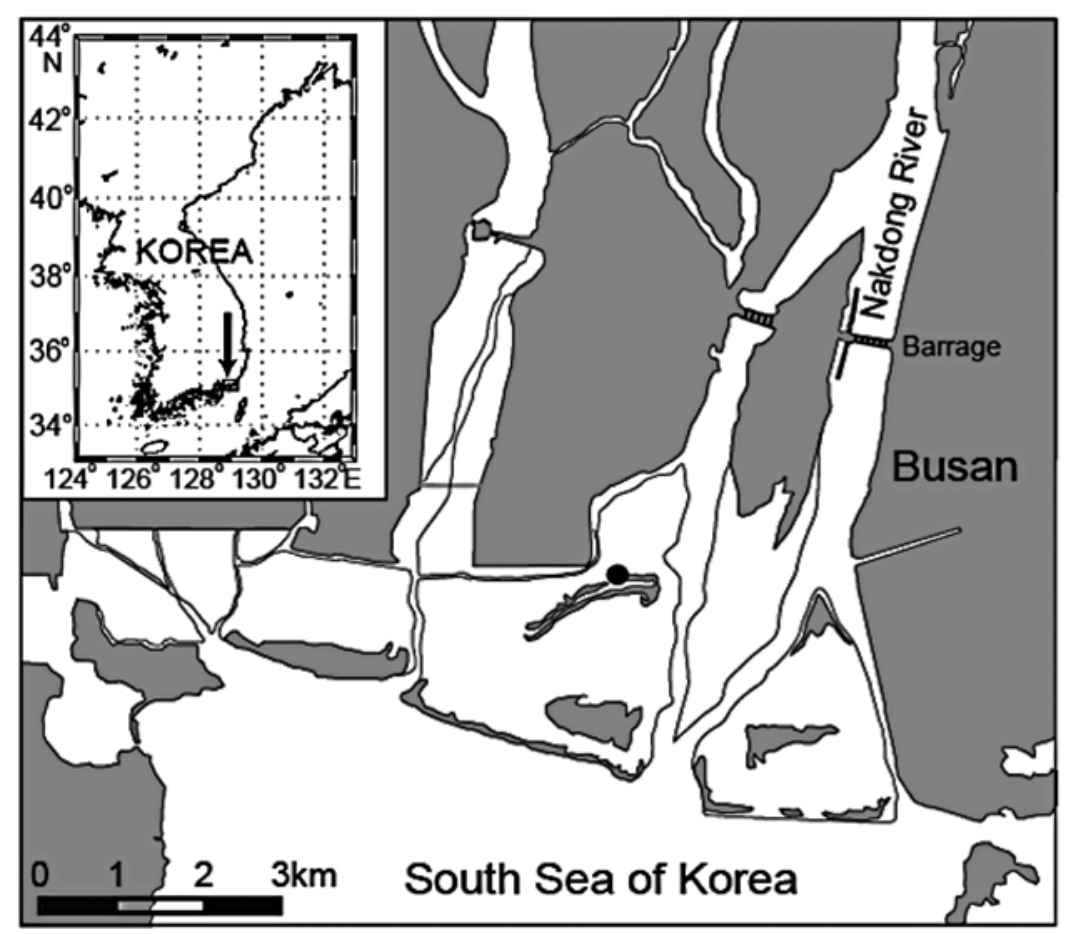

Fig. 1. The Nakdong Estaury on the southeastern coast of the Korean Peninsula. The black dot indicates the study site 
experimental error during sample processing precluded detection of enrichment. The uptake kinetics study was therefore repeated for ammonium and nitrate in January 2008.

Field sampling. Sampling was undertaken on 16 and 17 August 2007 to determine profiles of porewater nutrient concentrations, pigments, and particulate organic nitrogen (PON) and carbon (POC) in the sediment, and environmental parameters (salinity, PAR, temperature, water depth) at the water-sediment interface. On both days, sampling was conducted at $2 \mathrm{~h}$ intervals from before sunrise (05:00 h local time) to after sunset (20:00 h).

Porewater was sampled using the rhizon method (Seeberg-Elverfeldt et al. 2005). Three specially designed cores $(10 \mathrm{~cm} \varnothing)$ with holes at $0.5 \mathrm{~cm}$ intervals along their lengths (closed with adhesive tape during sampling), were gently pushed into the sediment. As the water was shallow ( $<1 \mathrm{~m}$ at all times), core sampling was done on foot during all tidal periods. Rhizons (Rhizosphere Research Products) were then used to sample the porewater at intervals from the interface to a depth of $2.5 \mathrm{~cm}$. Rhizons are made of hydrophilic porous polymer tubes (pore diameter $0.1 \mu \mathrm{m}$ ) extended with a polyvinyl chloride tube. The outer diameter of a rhizon is $2.4 \mathrm{~mm}$, and the filter section is $5 \mathrm{~cm}$ long. At the end of the rhizon, there is a valve connector that can be attached to a $15 \mathrm{ml}$ syringe. The rhizon was gently pushed through the holes into the sediment. The syringe was held open using a plastic block, creating a vacuum. Sampling took place for approximately 15 min, after which the valve connector was closed and the sample was transfered to a $15 \mathrm{ml}$ tube and frozen at $-4^{\circ} \mathrm{C}$ until analysis for $\mathrm{NO}_{\mathrm{x}}$ (nitrate and nitrite) and ammonium.

Sediment samples were collected for pigment analysis using a modified version of the cryolander method (Wiltshire et al. 1997). During low tide, $3 \mathrm{~cm} \varnothing$ tubes were pushed into the sediment and the sediment was frozen by gently pouring liquid nitrogen into the core. A total of 6 cores were sampled at each time period. During high water periods, larger $9 \mathrm{~cm} \varnothing$ cores were sampled, and immediately subsampled with the smaller corers. The sediment was kept frozen at $-80^{\circ} \mathrm{C}$ until sectioning for pigment and POC/PON analysis.

Environmental parameters such as salinity, temperature and water depth were recorded at 1 min intervals over the entire sampling period using a Hydrolab DataSonde 4 (HYDROLAB) multi-parameter logging system placed at the interface. Light values at the surface of the sediment were taken with a Hobo light intensity probe (Onset Computer Corp).

Kinetic uptake incubations. Uptake kinetics of ammonium and nitrate were studied using the ${ }^{15} \mathrm{~N}$ stable isotope tracer technique (Dugdale \&Wilkerson 1986).
Three separate experiments were carried out. On 20 August 2007, a kinetic experiment was undertaken to determine MPB ammonium uptake. A diurnal study of the uptake of this nutrient was also done on $22 \mathrm{Au}-$ gust. Following this, the kinetics experiment was repeated on 9 January 2008 to measure the uptake of ammonium and nitrate.

Surface sediment samples were collected from the study site on 19 and 21 August 2007 and 8 January 2008. The sediment was then placed in a basin overnight and MPB were concentrated the following morning using the lens tissue method. Lens tissue was placed on the sediment over concentrated patches of MPB that were visible to the naked eye. The cells transfer to the lens tissue by capillary action. Subsequently, the cells were transferred from the lens tissue into a beaker using a pipet, and diluted in filtered nutrient-poor water from the study site. Silicic acid $\left(50 \mu \mathrm{mol} \mathrm{l} \mathrm{l}^{-1}\right)$ and phosphates $\left(3 \mu \mathrm{mol}{ }^{-1}\right)$ were added to the water to prevent depletion during incubation. At this point, a $100 \mathrm{ml}$ sample was filtered onto a GFF filter and stored at $-20^{\circ} \mathrm{C}$ for determination of pigments. A sample of the cells was also fixed with Lugol's solution for determination of species present and cell counts. The remaining water containing the MPB was then separated into 60 polycarbonate incubation flasks $(250 \mathrm{ml})$, and isotopic solutions $\left({ }^{15} \mathrm{NaNO}_{3}\right.$ and $\left.{ }^{15} \mathrm{NH}_{4} \mathrm{Cl}\right)$ were used to enrich the samples to the following 10 concentrations: $0,1,2,4,8,15,30,60,120$ and $200 \mu \mathrm{mol} \mathrm{l}^{-1}$. Each enrichment series was done in triplicate. Following enrichment and mixing of the bottles, a $5 \mathrm{ml}$ subsample was taken to measure nutrient concentrations at the beginning of the experiment. Incubations were carried out for approximately $4 \mathrm{~h}$ in an incubation bath outside the laboratory. Light and temperature were monitored in the incubation bath during the incubations. Temperature was $6.6 \pm 0.2^{\circ} \mathrm{C}$ in winter and $31.5 \pm 0.6^{\circ} \mathrm{C}$ in summer. Light availability was $158.4 \mu \mathrm{mol}$ photons $\mathrm{m}^{-2} \mathrm{~s}^{-1}$ in winter and $132 \mu \mathrm{mol}$ photons $\mathrm{m}^{-2} \mathrm{~s}^{-1}$ in summer. After a $4 \mathrm{~h}$ incubation period, the samples were filtered on precombusted $\left(400^{\circ} \mathrm{C}\right.$, $4 \mathrm{~h}) 25 \mathrm{~mm}$ GFF filters and immediately dried and stored at $60^{\circ} \mathrm{C}$ until analyses.

On the 22 August a series of $8 \times 2 \mathrm{~h}$ incubations were carried out between 05:00 and 20:00 h (local time) to measure the oscillation of uptake over the diurnal period. During each incubation, 4 bottles were inoculated with $10 \%{ }^{15} \mathrm{NH}_{4} \mathrm{Cl}$ (final concentration $6.9 \pm$ $2 \mu \mathrm{mol} \mathrm{l^{-1 }}$ ). One of the bottles was placed in the dark while the other 3 were exposed to natural light conditions. The temperature over the entire incubation period was $31.2^{\circ} \mathrm{C} \pm 0.85$.

Sample processing and analysis. Concentrations of $\mathrm{NO}_{\mathrm{x}}$ and ammonium were analyzed according to Strickland \& Parsons (1968). The sediment cores taken 
for pigment analyses were sectioned at a number of depths using a cryotome (LEICA, CM 1500). Cores were cut to depths of $0.2 \mathrm{~mm}, 1 \mathrm{~mm}, 3 \mathrm{~mm}, 5 \mathrm{~mm}, 1 \mathrm{~cm}$ and $2 \mathrm{~cm}$. The samples were then analysed for pigments using high performance liquid chromatography (HPLC). The pigments were extracted with $5 \mathrm{ml}$ of acetone $(90 \%)$ for $24 \mathrm{~h}$ at $-20^{\circ} \mathrm{C}$. The subsequent HPLC analysis method is described in Kang et al. (2006). MPB cell counts were carried out using an inverted micrcoscope (LEICA); total cell numbers were counted on 150 grids on a grid counting chamber (5250 grids, $500 \mu \mathrm{l}$ sample).

The filters for stable isotope analysis were transferred to small tin capsules and oxidised at $1030^{\circ} \mathrm{C}$ in a Eurovector 3000 Series elemental analyzer (EA). The resul-

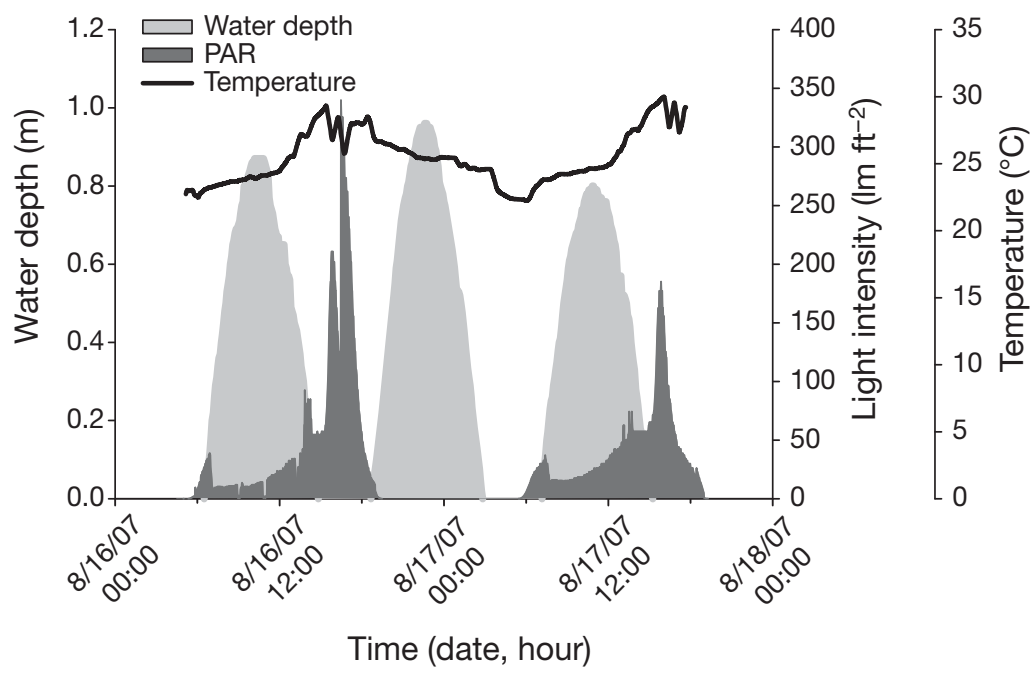
tant $\mathrm{N}_{2}$ was analysed for stable isotope

Fig. 2. Environmental parameters measured over the course of the $2 \mathrm{~d}$ sampling period in August 2007

ratios with a Micro-mass Isoprime continuous-flow isotope-ratio mass spectrometer (CF-IRMS). Concurrently, particulate organic nitrogen was measured for each sample using a standard curve of PON. The samples were not corrected for stable isotope dilution as little dilution would be expected at the relatively high concentrations used (Glibert et al. 1982), and also the incubation times can be considered relatively short ( 2 to $4 \mathrm{~h}$ ) (Dugdale \& Wilkerson 1986).

Uptakes of ammonium and nitrate $\left(V, \mathrm{~h}^{-1}\right)$ were calculated using Eq. (2) of Dugdale \& Wilkerson (1986):

$$
V=\frac{{ }^{15} \mathrm{~N} \text { atom } \% \text { excess }}{{ }^{15} \mathrm{~N} \text { atom } \% \text { enrichment }} \times \text { incubation time }
$$

where the ${ }^{15} \mathrm{~N}$ atom $\%$ excess is the ${ }^{15} \mathrm{~N}$ atom of the particulate fraction minus normal ${ }^{15} \mathrm{~N}$ atom $\%,{ }^{15} \mathrm{~N}$ atom $\%$ enrichment is the initial enrichment of ammonium or nitrate in the medium (we assume that $V$ remains constant during the incubation). In the case of ammonium, the mean value (before and after incubation) was used in the calculation to reduce the influence of regeneration processes (Raimbault et al. 1999). In the case of the nitrate uptake experiments, it can be assumed that the influence of nitrification processes were minimal because (1) the ammonium concentrations were close to zero and (2) concentrations of ${ }^{15} \mathrm{NaNO}_{3}$ were high. However, as neither the regeneration of organic $\mathrm{N}$ nor nitrification (both of which can result in stable isotope dilution) were considered in the calculation of the nitrate uptake rates, estimates reported here are considered to be conservative.

The uptake curve of ammonium and nitrate was then fitted to the Michaelis-Menten equation (triplicate data used in each case):

$$
V=\frac{V_{\max } \times S}{K_{\mathrm{s}}+S}
$$

where $V$ is the uptake rate $\left(\mathrm{h}^{-1}\right), V_{\max }$ is the maximal

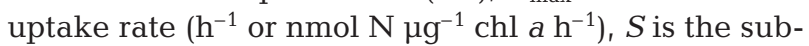
strate concentration $\left(\mu \mathrm{mol} \mathrm{l^{-1 }}\right)$, and $K_{\mathrm{s}}\left(\mu \mathrm{mol} \mathrm{l^{-1 }}\right)$ is the half-saturation constant (concentration at which $V=$ $\left.V_{\max } / 2\right) . V_{\max }$ and $K_{\mathrm{s}}$ parameters and their standard errors were estimated by fitting the data with the nonlinear method of Wilkinson (1961).

Statistical tests of differences between light and dark uptake rates were conducted using the STATGRAPHIC PLUS V 5.8 program. Data were tested for normality (Shapiro-Wilk test) and equality of variance (Levene test). Data were not normally distributed; accordingly, we performed Kruskal-Wallis non-parametric ANOVA tests followed by Mann-Whitney $U$-tests.

\section{RESULTS}

\section{Environmental parameters at the study site}

The tidally controlled water depth oscillated by approximately $0.95 \mathrm{~m}$ through the study period (Fig. 2). Three submersion periods of approximately $6 \mathrm{~h}$ duration occurred during the study time. Temperature increased by up to $9^{\circ} \mathrm{C}$ between night and day exposure periods. The alterations in light availability were strongly related to the tidal and diurnal cycles, with highest values at approximately 16:00 h (local time) on both days (Fig. 2). Over the 2 d sampling period, salinity showed oscillations that corresponded to the changes in the tidal cycle, ranging from 2.75 during the flooding tide to 10.5 immediately following high tide (data not shown). 


\section{DIN porewater profiles}

The concentrations of ammonium and $\mathrm{NO}_{\mathrm{x}}$ in the sediment porewater showed clear and opposing oscillations on both sampling days (Fig. 3). Ammonium decreased during submersion periods at all sediment depths, suggesting a diluting influence of the tidal current on the porewater concentrations (Fig. 3A). Indeed, overlying water concentrations for this season were approximately $2.5 \mu \mathrm{mol} \mathrm{l^{-1 }}$. The large increase in concentrations during emersion throughout the sediment depths suggests elevated remineralisation activity, while the lower values at the interface and at $0.5 \mathrm{~cm}$ are probably a result of MPB assimilation and microbial nitrification processes. In all, a considerable ammonium concentration range was measured, from low values of almost zero in the surface sediments during submersion to highest values of approximately $220 \mu \mathrm{mol} \mathrm{l}^{-1}$ in the deepest sediments during emersion.

The trend in $\mathrm{NO}_{\mathrm{x}}$ was reversed (Fig. 3B), with higher concentrations found during submersion (average \pm SD of all surface values: $98.3 \pm 70 \mu \mathrm{mol} \mathrm{l}^{-1}$ ), while concen- trations decreased during emersion to almost zero, especially in deeper sediments. Again the tidal influence was apparent; in this case submersion significantly increased the concentration due to the high $\mathrm{NO}_{\mathrm{x}}$ concentrations in the overlying waters (ca. $150 \mu \mathrm{mol} \mathrm{l}^{-1}$ ). The fall in $\mathrm{NO}_{\mathrm{x}}$ during emersion is possibly a result of microbial processes that can reduce concentrations, e.g. denitrification and dissimilatory nitrogen reduction. Concentrations of both ammonium and $\mathrm{NO}_{\mathrm{x}}$ had a sigmoidal correlation with tidal height (Table 1); this relationship was strongest in shallowest porewater depths, and decreased to non-significant at $2.5 \mathrm{~cm}$.

\section{Sediment chl a profiles}

The migration of MPB to the sediment surface during the diurnal emersion periods can be clearly observed in Fig. 4. At the first sampling time immediately before sunrise $(05: 00 \mathrm{~h})$, the biomass was largely concentrated in the top $200 \mu \mathrm{m}$ of the sediment (Fig. 4A). As the water level rose (after 09:00 h), a large reduction in the

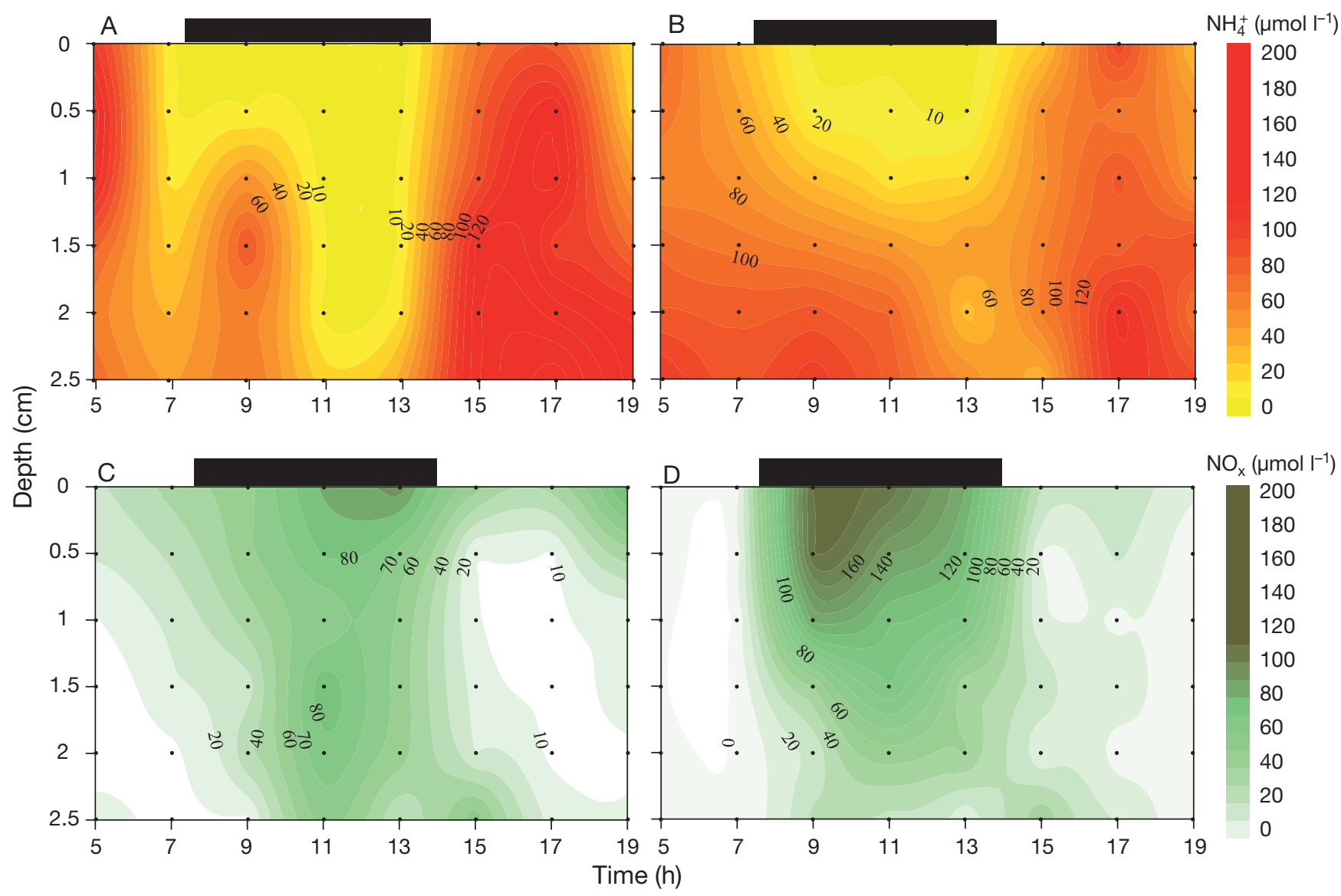

Fig. 3. Contour maps of $(A, B)$ ammonium and $(C, D) N_{x}$ concentrations by sediment depth and time in the porewaters of the study site over the $2 \mathrm{~d}$ sampling period. Black bars: high tide periods. Data prepared for presentation with Surfer software (version 8) 
biomass at the surface occurred due to vertical migration of the MPB down into the sediment. The increasing concentrations at the beginning of emersion $(15: 00 \mathrm{~h})$ suggest a re-emergence of the MPB at the sediment surface. Following this, the biomass again began to migrate down into the sediment at sunset (19:00 h). A similar migration pattern was repeated for the second day of sampling (Fig. 4B). Approximately $70 \%( \pm 13 \% \mathrm{SD})$ of the biomass of MPB was found in the first $\mathrm{mm}$ of sediment during the emersion period; moreover, the concentration of chl $a$ at this depth was significantly higher during emersion periods than during submersion (paired $t$-tests, $\mathrm{p}<0.05$ ).

\section{Taxonomic characterisation of microphytobenthos extracts}

Microscopic examination of the MPB extracted for uptake experiments revealed that in all experiments the diatom genus Navicula was dominant (85 $\pm 15 \%$ SD), with small Navicula spp. being most prevalent $(65 \pm 9 \%)$. Nitzschia longissima was also present in all samples (1\% in summer samples and $24 \%$ in winter), while in summer a number of Amphora spp. were found $(2.2 \pm 1.1 \%)$. The MPB taxa were in accord with observations on natural population (Du et al. pers. obs.). The total number of MPB cells in the solution used for the kinetic experiment was $7.7 \times 10^{7} 1^{-1}$ in summer and $7.0 \times 10^{6} \mathrm{l}^{-1}$ in winter. No microalgae cells others than diatoms, (mostly benthic species) were observed. Detritus and empty frustules made up a portion of each sample. Concentrations of chl a for the summer and winter kinetics experiments were 4.0 and $7.0 \mu \mathrm{g} \mathrm{l}^{-1}$, respectively. The POC:PON ratio calculated during stable isotope measurements and for all the incubations performed was estimated at $5.23 \pm 1.84(\mathrm{~mol} / \mathrm{mol})$.

\section{Uptake kinetics of ammonium and nitrate}

The uptake of ammonium measured in August 2007 (Fig. 5A) fitted Michaelis-Menton kinetics up to con-

Table 1. Sigmoidal relationship between tidal height and nitrate and ammonium concentrations in the porewater. Analysed with SPSS software, version 12.0. ${ }^{*} \mathrm{p}<0.01,{ }^{* *} \mathrm{p}<0.001,{ }^{* * *} \mathrm{p}<0.0001$

\begin{tabular}{|c|c|c|c|c|c|c|}
\hline \multirow{2}{*}{$\begin{array}{l}\text { Tidal height } \\
\text { (cm) }\end{array}$} & \multicolumn{3}{|c|}{$-\mathrm{NO}_{\mathrm{X}}\left(\mu \mathrm{mol} \mathrm{l} \mathrm{l}^{-1}\right)$} & \multicolumn{3}{|c|}{ Ammonium $\left(\mu m o l l^{-1}\right)$} \\
\hline & $\mathrm{r}^{2}$ & $F$ & $\mathrm{p}$ & $\mathrm{r}^{2}$ & $F$ & $\mathrm{p}$ \\
\hline 0.0 & 0.44 & 11.08 & ${ }^{* *}$ & 0.87 & 81.35 & *** \\
\hline 0.5 & 0.47 & 15.72 & $* * *$ & 0.64 & 30.66 & $* * *$ \\
\hline 1.0 & 0.43 & 14.14 & $* * *$ & 0.51 & 20.10 & *** \\
\hline 1.5 & 0.44 & 13.78 & $* * *$ & 0.2 & 4.48 & ${ }^{*}$ \\
\hline 2.0 & 0.49 & 19.20 & ${ }^{* * *}$ & 0.16 & 3.54 & 0.04 \\
\hline 2.5 & 0.01 & 0.19 & 0.83 & 0.13 & 2.64 & 0.09 \\
\hline
\end{tabular}

centrations of $60 \mu \mathrm{mol} \mathrm{\textrm {l } ^ { - 1 }}$. Above this concentration, the uptake was distinctly higher suggesting a type of multiphasic assimilation. Considering solely the lower curve $\left(<60 \mu \mathrm{mol} \mathrm{\textrm {l } ^ { - 1 } )}\right.$ we calculated a $K_{\mathrm{s}}$ value of $11.8 \mu \mathrm{mol} \mathrm{l}^{-1}$ and a $V_{\max }$ of $0.02 \mathrm{~h}^{-1}$ (Table 2). The high $K_{\mathrm{s}}$ calculated signifies low affinity uptake at low ammonium concentrations. In contrast, the curve for the winter population of diatoms shows an overall lower rate of uptake, while the Michaelis-Menton model can be fitted to the highest concentration used $\left(200 \mu \mathrm{mol} \mathrm{l}^{-1}\right)$. The calculated $K_{\mathrm{s}}$ is considerably lower $\left(1.5 \mu \mathrm{mol} \mathrm{l^{-1 }}\right)$, indicating that the MPB is more efficient at taking up ammonium at lower concentrations during this season.

In winter, the nitrate uptake rates were much lower than those for ammonium (Fig. 5B, $V_{\max }=0.001 \mathrm{~h}^{-1}$, Table 2). Interestingly, the $K_{\mathrm{s}}$ value $\left(19.2 \mu \mathrm{mol} \mathrm{l^{-1 }}\right)$ is above that of ammonium during the summer period, reflecting perhaps an acclimation of the MPB to high nitrate values. In this case, the Michaelis-Menten model was fitted through $120 \mu \mathrm{mol}^{-1}$ (i.e. uptake rates at higher concentrations were omitted) as this showed the best fit to the data.

\section{Ammonium uptake over the diurnal cycle}

The ammonium uptake over the diurnal cycle differed distinctly between light and darkened/night incubations (Fig. 6). The first natural light incubation (05:00 h) preceded sunrise and was significantly different from the subsequent incubations (Mann-Whitney $U$-test, $\mathrm{p}<$ 0.05). Following this early morning incubation, the uptake rates were $\sim 50 \%$ lower in darkness at all times. There was no apparent trend between uptake rates and time of day between sunrise and sunset; rates varied only slightly over the diurnal period $\left(0.06 \pm 0.01 \mathrm{~h}^{-1}\right)$. Similarly, darkened/night rates were also highly constant through time $\left(0.03 \pm 0.01 \mathrm{~h}^{-1}\right)$. Significant differences were found between the light and darkened/night incubations (Mann-Whitney $U$-test, p < 0.05).

\section{DISCUSSION}

\section{Ammonium and nitrate uptake by MPB}

The results of this study present a first attempt to parameterise DIN uptake kinetic of a natural MPB community. The ammonium uptake rates in winter and summer fitted very different kinetic curves (Fig. 5). Although $K_{\mathrm{s}}$ and $V_{\max }$ estimates were in the range of 


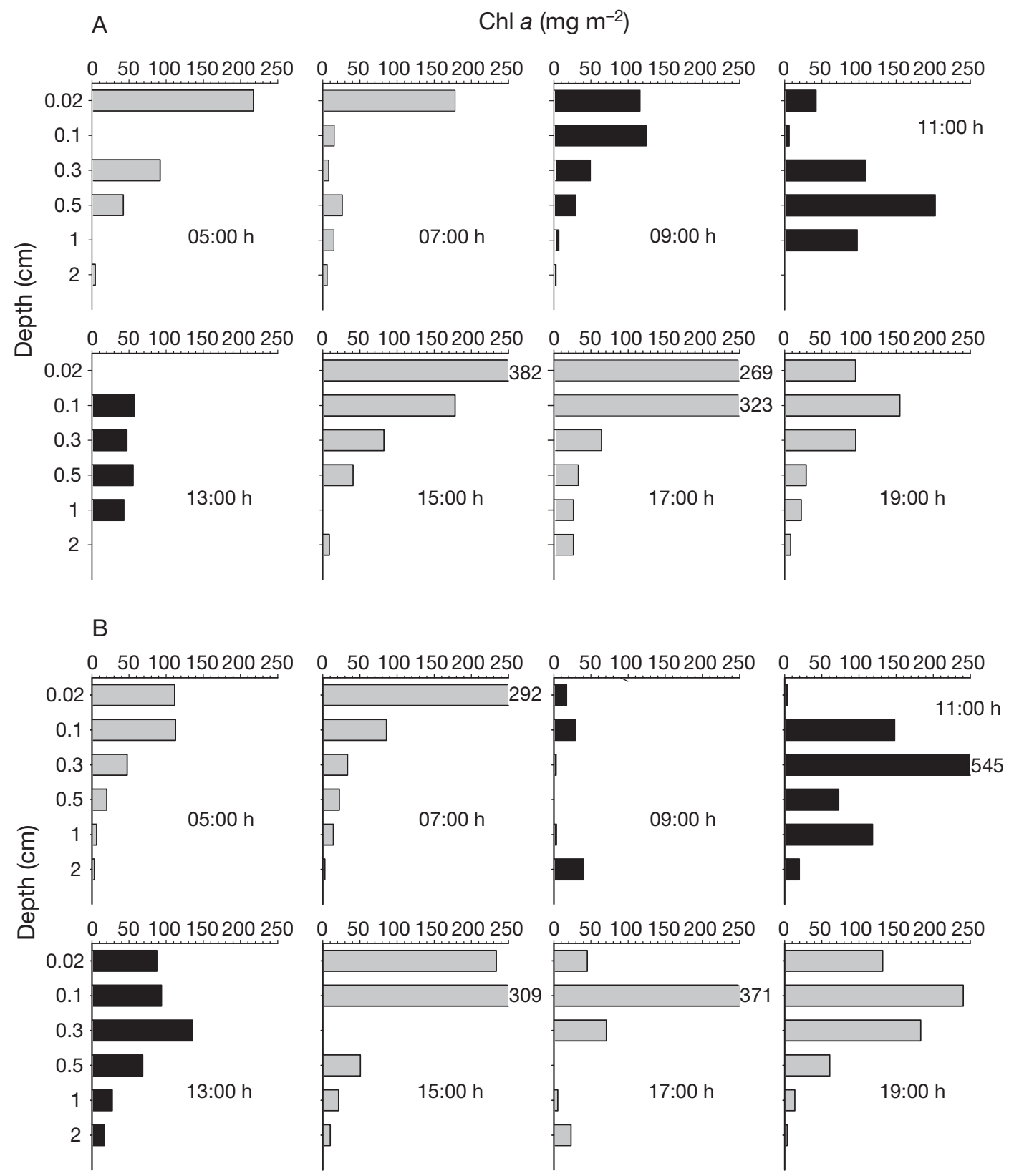

Fig. 4. Profiles of chl a concentrations over the $2 \mathrm{~d}$ sampling period. (A) Day 1, (B) Day 2. Grey bars: low tide periods; black bars: submersion periods. Values inserted to the right of histogram bars indicate concentrations of $>250 \mathrm{mg} \mathrm{chl} \mathrm{a} \mathrm{m}^{-2}$

values observed for phytoplankton (Wheeler et al. 1982, Shiomoto et al. 1994, Collos et al. 2005), they differed by one order of magnitude between seasons (Table 2), suggesting external regulation of uptake. Changes in uptake rates may result from regulatory response mechanisms controlled by physiological or ecological factors related to substrate conditions, irradiance, day length, temperature and community structure (Eppley et al. 1969, Berges et al. 2002, reviewed in Collos et al. 2005).
Adaptation of the MPB to ambient ammonium concentrations influences the kinetics curve shape, and in particular the $K_{\mathrm{s}}$ value, which gives information on substrate affinity (Eppley et al. 1969). In summer, ammonium porewater concentrations varied greatly over $2 \mathrm{~d}$ and reached very high levels during emersion periods, which probably relates to the remineralisation of organic material (Fig. 3A,B). In winter, although porewater concentrations were not measured, the low level of organic material in the overall estuarine sys- 


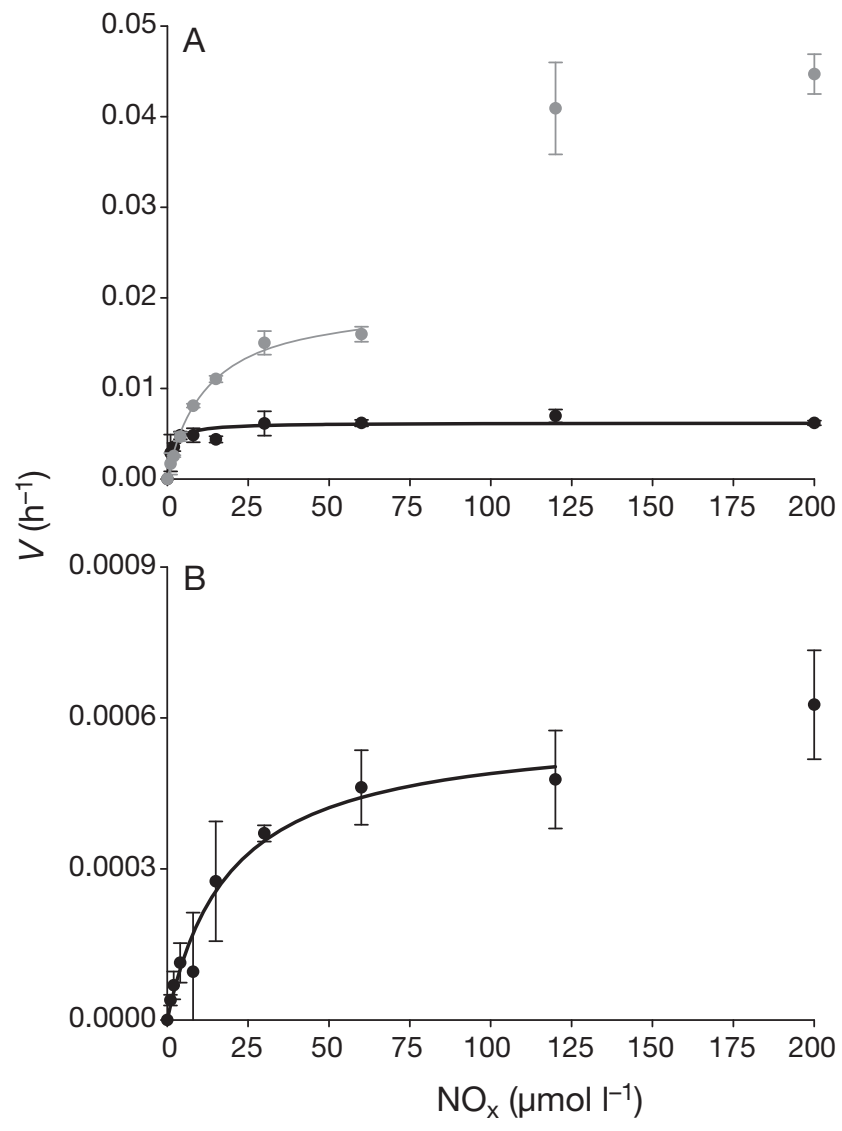

Fig. 5. Uptake kinetics of (A) ammonium and (B) nitrate by the microphytobenthos. Grey: August; black: winter. Note that $y$-axes differ by 2 orders of magnitude. $V$ : uptake rate. Error bars: SE

tem and intertidal area (Choy et al. 2008) and the lower temperature may depress remineralisation rates and hence ammonium levels in the sediment. Therefore, the relatively lower $\mathrm{K}_{\mathrm{s}}$ value during winter probably results from a shift in the functioning of the MPB population towards an affinity for lower rather than higher concentrations. This shift in the uptake mechanism between seasons would allow the MPB to stay competitive in periods of ambient concentration oscillation (Harrison et al. 1996).

Table 2. Variability in determined values of $K_{\mathrm{s}}$ and $V_{\max }$, for 3 kinetic experiments. Data are mean $( \pm \mathrm{SE}$, where shown)

\begin{tabular}{|c|c|c|c|}
\hline & $\begin{array}{c}\mathrm{NH}_{4}^{+} \\
\text {Summer }\end{array}$ & $\begin{array}{c}\mathrm{NH}_{4}^{+} \\
\text {Winter }\end{array}$ & $\begin{array}{c}\mathrm{NO}_{\mathrm{x}} \\
\text { Winter }\end{array}$ \\
\hline Range of concentrations $\left(\mu \mathrm{mol} \mathrm{l}^{-1}\right)$ & $0-60$ & $0-200$ & $0-120$ \\
\hline $\mathrm{N}$ & 24 & 30 & 27 \\
\hline$K_{\mathrm{s}}\left(\mu \mathrm{mol} \mathrm{l}^{-1}\right)$ & $11.8 \pm 1.2$ & $1.5 \pm 0.4$ & $19.2 \pm 3.0$ \\
\hline$V_{\max }\left(\mathrm{h}^{-1}\right)$ & $0.02 \pm 0.001$ & 0.006 & 0.001 \\
\hline$V_{\max }\left(\mathrm{nmol} \mathrm{N} \mu g \mathrm{chl} a^{-1} \mathrm{~h}^{-1}\right)$ & 0.077 & $0.016 \pm 0.001$ & 0.001 \\
\hline
\end{tabular}

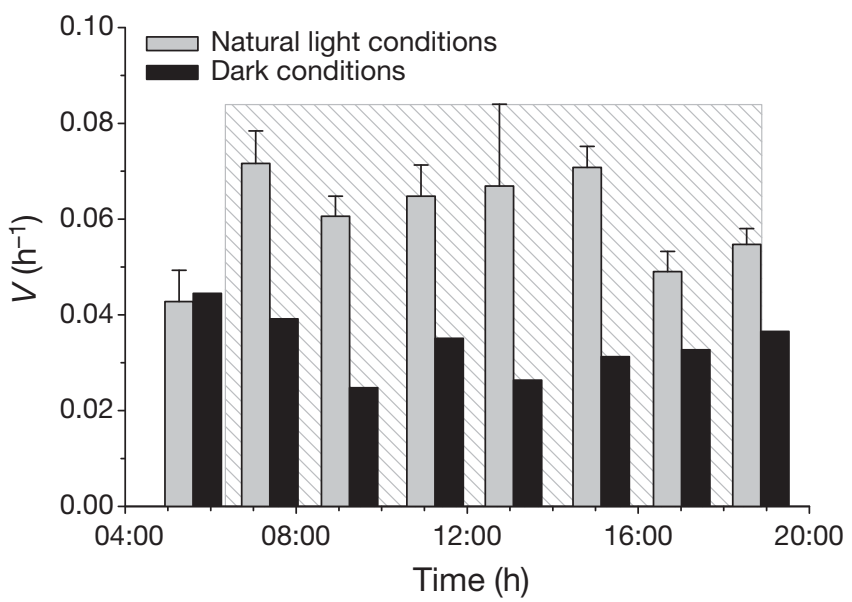

Fig. 6. Assimilation of ammonium by the microphytobenthos over the diurnal cycle (hatched rectangle: light period). All dark incubation bottles were acclimatised to natural light prior to incubation in darkness. Means $+\mathrm{SD}, \mathrm{n}=3$

The summer ammonium kinetics show the presence of a multiphasic assimilation, whereby as the substrate concentrations increased, an alternate mechanism (either related to diffusion or a second active uptake system) was induced. Studies of nitrate uptake kinetics of phytoplankton have demonstrated a phase transition point at approximately the same concentration $\left(60 \mathrm{~mol} \mathrm{l}^{-1}\right)$ as that in the present study (Lomas \& Glibert 1999b, 2000, Collos et al. 2005). Our previous work also revealed a similar mechanism during silicic acid uptake by the MPB at high concentrations (Leynaert et al. 2009). However, to our knowledge, there is little evidence for a similar process for ammonium. Ammonium kinetic experiments are rarely carried out using concentrations above 30 to $40 \mathrm{\mu mol} \mathrm{l}^{-1}$ (Wheeler et at. 1982, Shiomoto et al. 1994); this is not surprising as in situ values of ammonium in coastal and certainly oceanic waters rarely rise above these values (reviewed in L'Helguen et al. 1996). Short-term uptake experiments ( 1 to $5 \mathrm{~min}$ ) on a natural phytoplankton population (Wheeler et al. 1982) found a linear relationship between uptake and ammonium concentration, which suggested a 'nonmediated uptake process such as diffusion' (p. 1123). This type of process is thought to equilibrate external and internal pools of ammonium, which leads to an increase in internal pool size (Dortch et al. 1984. Another plausible explanation would be the presence of several types of transporters with various affinities, as proposed in a recent study of silicic acid uptake in the MPB (Leynaert et al. 2009). The winter kinetics curve showed a constant maximal uptake through 
$200 \mu \mathrm{mol} \mathrm{l}^{-1}$, with no indication of a second uptake system. This implies a saturation of the uptake system at these very high concentrations.

While direct comparisons between the 2 communities (winter and summer) cannot be made, the differences in shapes of the 2 uptake curves may be related to experimental temperature differences. Temperatures in summer were considerably higher (31.5 \pm $\left.0.6^{\circ} \mathrm{C}\right)$ than in winter $\left(6.6 \pm 0.2^{\circ} \mathrm{C}\right)$. The influences of temperature on relative and maximal assimilation rates of ammonium have been demonstrated previously in natural diatom-dominated communities (Lomas \& Glibert 1999b, Harrison et al. 1996). This regulation is related to activity of the enzyme involved in ammonium assimilation (glutamate synthase, GOGAT), which may have optimal activity at around $25^{\circ} \mathrm{C}$ (Clayton \& Ahmed 1986). Hence, summer temperatures would have been close to the optimal temperature, while winter low temperatures may have led to a reduction in uptake rate.

The nitrate kinetics, while consistent with previous measurements for in situ phytoplankton (McCarthy et al. 2007), had a considerably lower specific uptake rate at all concentrations when compared to ammonium (Fig. 5). Previous authors have observed a similar trend (Shiomoto et al. 1994), although not to the extent shown here. This low rate during winter may, like the ammonium uptake, be influenced by temperature. Nitrate reductase, the enzyme associated with nitrate reduction in diatom species, has a thermal optimum near $16^{\circ} \mathrm{C}$, and nitrate assimilation can increase significantly with temperature (Lomas \& Glibert 1999b, Berges et al. 2002 and references therein). Despite the low uptake rate, the $K_{\mathrm{s}}\left(19.2 \mu \mathrm{mol} \mathrm{l}^{-1}\right)$ was rather high. This suggests that the MPB is more efficient at assimilating nitrate at high substrate concentrations. The uptake at $200 \mu \mathrm{mol} \mathrm{l^{-1 }}$ was distinctly above the fitted kinetics curve, and is again indicative of a probable second uptake system (Lomas \& Glibert 2000). Similar high phase transition values have been previously observed for phytoplankton (Collos et al. 2005).

The results presented in Fig. 6 confirm that assimilation of ammonium by the MPB was reduced during night and daytime experimentally darkened conditions. Flux studies in subtidal (Sundbäck et al. 1991, Sundbäck \& Miles 2000) and intertidal areas (FeuilletGirard et al. 1997, Thornton et al. 1999, 2007, Sakamaki et al. 2006) have previously inferred a decrease in assimilation during dark periods. Similarly, Thornton et al. (1999), through measurement of rates of ammonium decrease in a medium containing suspended MPB, demonstrated uptake rates 2 to 5 times higher in light than in dark incubations; this is similar to the $50 \%$ increase we observed under illumination. Overall, previous and current studies suggest a link between the ion uptake process and photosynthesis. Indeed, although the MPB in the current study was maintained in natural light conditions until moments before the beginning of the dark incubations, the rapid change in light conditions induced a rapid decrease in mineral nutrient assimilation rate. This implies that the energy acquired during light exposure was insufficient to fuel a comparable uptake rate during the following dark incubation (2 h).

\section{Influence of in situ migration and nutrient oscillations on uptake}

The MPB live in an environment that is characterized by extreme physical and chemical gradients. Their exposure to oscillations in light, temperature and nutrients is defined firstly by diurnal and tidal cycles and secondly by the ability of cells to migrate through the superficial sediment layers of the mudflat. The changes in MPB biomass measured as chl a concentrations (Fig. 4) were consistent with profiles previously examined in intertidal estuarine areas (de Brouwer \& Stal 2001, Herlory et al. 2004). The profiles show an active migration to the surface (first $\mathrm{mm}$ ) of the sediment during emersion, while during submersion the biomass was spread throughout the first $2 \mathrm{~cm}$. The importance of this migration in terms of DIN assimilation pertains firstly to the influence it has on light availability and secondly on the substrate concentrations to which the cells are exposed.

As shown in Fig. 6, light condition will directly influence nutrient assimilation. When the MPB migrates away from the surface to below the photic zone (approximately $1 \mathrm{~mm}$ in sandy-mud sediments, Kühl \& Jørgensen 1994), the uptake of ammonium is dramatically reduced. Taking this into account, we can speculate that cells migrating below $1 \mathrm{~mm}$ sediment depth, or indeed the entire population during night periods, will experience a reduction in assimilation rates.

There has been speculation that one of the reasons MPB migrate into deeper sediments is to access the high concentrations of nutrients available in subsurface layers (Happey-Wood \& Jones 1988, Barranguet et al. 1998, Kingston 2002). Measured substrate concentrations by depth in our study site were more variable temporally than spatially (i.e. vertically). The oscillation was principally influenced by the tidal cycle, as demonstrated conclusively in other intertidal sediment systems (Sakamaki et al. 2006). Indeed, the increase in ammonium and decrease in NOx in porewaters during emersion that we observed (Fig. 3) have been demonstrated previously (Usui et al. 1998, Kuwae et al. 2003). 
In the case of ammonium, the interface concentrations were much higher during emersion (when the cells were at the surface) than through the entire profile during submersion. Added to the positive influence of light, we can conclude that the MPB will preferentially take up this nutrient while at the surface rather than during periods when they are below the photic zone. Thus, as was certainly the case for ammonium during our study period, the downward vertical migration process would not appear to be related to a requirement for substrate as the cells would have already replenished their stocks while at the surface.

The preference of phytoplankton and MPB for ammonium over nitrate has been discussed in a number of studies (Syrett \& Morris 1963, Admiraal et al. 1987, Sundbäck et al. 1991, Feuillet-Girard et al. 1997, Cook et al. 2004); moreover, the addition of ammonium to cells growing on nitrate can rapidly result in a shift to ammonium rather then nitrate uptake (Lomas \& Glibert 1999a). Cells use substantially less energy to assimilate ammonium, as this source is a direct amino acid precursor, as opposed to nitrate, which has to be reduced intracellularly to ammonium using an assimilatory nitrate reductase (NR) before incorporation.

During tidal exposure periods in summer, ammonium concentrations at the interface were high (71 \pm

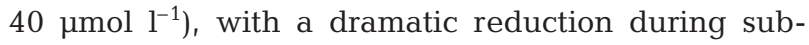
mersion $\left(14 \pm 19 \mu \mathrm{mol} \mathrm{l} \mathrm{l}^{-1}\right)$. Conversely, nitrate concentrations followed a distinctly reverse trend of lower emersion $\left(25 \pm 20 \mu \mathrm{mol} \mathrm{l}^{-1}\right)$ and high submersion concentrations $\left(98 \pm 70 \mu \mathrm{mol} \mathrm{l}^{-1}\right)$. Despite these oscillations, if we consider the concentration of ammonium given by Admiraal et al. (1987) as a threshold for suppression of nitrate uptake in the MPB $\left(5 \mu \mathrm{mol} \mathrm{l}^{-1}\right)$, we can argue that nitrate assimilation was suppressed or greatly reduced during the summer. Nonetheless, we have to be aware that nitrate uptake and assimilation may still occur in the presence of high ammonium concentrations (Lomas \& Glibert 1999a, Hildebrand \& Dahlin 2000). It would therefore be prudent to assume that nitrate assimilation, although in all probability small, may still occur. In fact, if we can assume that the alternating high concentrations of ammonium and nitrate during emersion-submersion are also present in winter, we may speculate that the high $K_{\mathrm{s}}$ value for nitrate could be a result of MPB acclimation to high nitrate concentrations during submersion when ammonium is depleted. This hypothesis needs to be tested with more experimental data.

These oscillating concentrations will, as already stated, have an influence on the suppression of nitrate uptake by ammonium, but also directly on the uptake rate of both DIN forms. If we consider the above mentioned concentrations of ammonium during submersion and emersion, the uptake could change from a possible $0.07 \mathrm{nmol} \mathrm{N} \mu \mathrm{g} \mathrm{chl} \mathrm{a}^{-1} \mathrm{~h}^{-1}$ during emersion to $0.04 \mathrm{nmol} \mathrm{N} \mu \mathrm{g} \mathrm{chl} a^{-1} \mathrm{~h}^{-1}$ during submersion, a drop of $37 \%$. We can therefore suppose that the cyclic nature of the exposure will have a substantial influence on the amount of ammonium assimilated by the MPB over time.

MPB nitrogen demand has been estimated using carbon:nitrogen elemental composition ratios. Sundbäck \& Miles (2000) chose a C:N ratio of 9, as this is the mean for epilithic microalgae and freshwater periphyton (Hillebrand \& Sommer 1997, Kahlert 1998), while Cook et al. (2004) assumed a ratio value of 6.6 (Redfield ratio) for benthic algal cells. Our study has revealed an average ratio of $5.23 \pm 1.84(\mathrm{~mol} / \mathrm{mol})$, which is in the lower range of values measured by Hillebrand \& Sommer (1997) for epilithic MPB, and below the value of 8.7 determined by Kahlert (1998) for freshwater MPB. This would suggest that the MPB in intertidal areas have a higher amount of internal $\mathrm{N}$ than previously suggested. C:N ratios are strongly related to nutrient supply (Flynn 1990) and from this we can infer that the elevated nitrogen levels found in intertidal sediments can result in a lower $\mathrm{C}: \mathrm{N}$ ratio than found in phytoplankton.

\section{CONCLUSION}

The present study has shown that environmental variables such as substrate concentration, light availability and temperature can influence the assimilation of DIN by the MPB. This concept is certainly not new in phytoplankton studies. However, because large oscillations in these parameters can occur over diurnal and tidal cycles, our findings have major implications for ecosystem modelling studies that incorporate contributions of the MPB into estimates of nutrient flux.

Nutrient cycling models often include the assumption that uptake of nutrients by the MPB can be represented by concepts and parameters quantified for the pelagic community without taking into account the influence of tidal and diurnal cycles. However, in the case of benthic primary production, the importance of tidal cycles for carbon uptake rates over time scales of days to seasons is recognised and considered imperative when modelling the influence of the MPB on benthic carbon production (Guarini et al. 2000, Serôdio \& Catarino 2000). Parameterisation and representation of MPB processes using information obtained directly from the study of in situ communities and their interaction with their environment would enable us to provide a more accurate representation of the influence of these autotrophs on nutrient cycles in coastal and estuarine sediments. 
Acknowledgements. The authors thank J. Grall, A. Masson, P. Claquin, J. H. Jung, and B. Clément-Larosière for their indispensable aid during the field sampling. Thanks also to H. J. Park for his help with the stable isotope sample analysis, and Du Guoying for cell counts. This project was funded by Brain Korea 21, the STAR France-Korea collaboration project, and The Eco-technopia 21 projects of Korean Ministry of Environment.

\section{LITERATURE CITED}

Admiraal W, Riaux-Gobin C, Laane RWPM (1987) Interactions of ammonium, nitrate, and D- and L-amino acids in the nitrogen assimilation of two species of estuarine benthic diatoms. Mar Ecol Prog Ser 40:267-273

Barranguet C, Kromkamp J, Peene J (1998) Factors controlling primary production and photosynthetic characteristics of intertidal microphytobenthos. Mar Ecol Prog Ser 173:117-126

Berges JA, Varela DE, Harrison PJ (2002) Effect of temperature on growth rate, cell composition and nitrogen metabolism in the marine diatom Thalassiosira pseudonana (Bacillariophyceae). Mar Ecol Prog Ser 225:139-146

Blackford JC (2002) The influence of microphytobenthos on the Northern Adriatic ecosystem: a modeling study. Estuar Coast Shelf Sci 55:109-123

Cahoon LB (1999) The role of benthic microalgae in neritic ecosystems. Oceanogr Mar Biol Annu Rev 37:47-86

Choy EJ, An S, Kang CK (2008) Pathways of organic matter through food webs of diverse habitats in the regulated Nakdong River estuary (Korea). Estuar Coast Shelf Sci 78: 215-226

Clayton JR, Ahmed SI (1986) Detection of glutamate synthase (GOGAT) activity in phytoplankton: evaluation of cofactors and assay optimisation. Mar Ecol Prog Ser 32: $115-122$

Collos Y, Vaquer A, Soucho P (2005) Acclimation of nitrate uptake by phytoplankton to high substrate levels. J Phycol 41:466-478

> Cook PLM, Revill AT, Butler ECV, Eyre BD (2004) Carbon and nitrogen cycling on intertidal mudflats of a temperate Australian estuary. II. Nitrogen cycling. Mar Ecol Prog Ser 280:39-54

de Brouwer JFC, Stal LJ (2001) Short-term dynamics in microphytobenthos distribution and associated extracellular carbohydrates in surface sediments of an intertidal mudflat. Mar Ecol Prog Ser 218:33-44

Dortch Q, Clayton JR, Thoresen SS, Ahmed SI (1984) Species differences in accumulation of nitrogen pools in phytoplankton. Mar Biol 81:237-250

Dugdale RC, Wilkerson FP (1986) The use of ${ }^{15} \mathrm{~N}$ to measure nitrogen uptake in eutrophic oceans: experimental considerations. Limnol Oceanogr 31:673-689

Eppley RW, Rogers JN, McCarthy JJ (1969) Half-saturation constants for uptake of nitrate and ammonium by marine phytoplankton. Limnol Oceanogr 14:912-920

Feuillet-Girard M, Gouleau D, Blanchard G, Joassard L (1997) Nutrient fluxes on an intertidal mudflat in MarennesOléron Bay, and influence of the emersion period. Aquat Living Resour 10:49-58

Flynn KJ (1990) The determination of nitrogen status in microalgae. Mar Ecol Prog Ser 61:297-307

Glibert PM, Lipschultz F, McCarthy JJ, Altabet MA (1982) Isotope dilution models of uptake and remineralization of ammonium by marine plankton. Limnol Oceanogr 27: $639-650$
Guarini JM, Blanchard GF, Gros P (2000) Quantification of the microphytobenthic primary production in European intertidal mudflats - a modelling approach. Cont Shelf Res 20:1771-1788

Happey-Wood C, Jones P (1988) Rhythms of vertical migration and motility in intertidal benthic diatoms with particular reference to Pleurosigma Angulatum. Diatom Res 3:83-93

Harrison WG, Harris LR, Irwin BD (1996) The kinetics of nitrogen utilization in the oceanic mixed layer: nitrate and ammonium interactions at nanomolar concentrations. Limnol Oceanogr 41:16-32

Herlory O, Guarini JM, Richard P, Blanchard GF (2004) Microstructure of a microphytobenthic biofilm and its spatio-temporal dynamics in an intertidal mudflat (Aiguillon Bay, France). Mar Ecol Prog Ser 282:33-44

Hildebrand M, Dahlin K (2000) Nitrate transporter genes from the diatom Clindrotheca fusiformis (Bacillariophyceae): mRNA levels controlled by nitrogen source and by the cell cycle. J Phycol 36:702-713

Hillebrand H, Sommer U (1997) Response of epilithic microphytobenthos of the Western Baltic Sea to in situ experiments with nutrient enrichment. Mar Ecol Prog Ser 160: $35-46$

Kahlert M (1998) C:N:P ratios of freshwater benthic algae. Arch Hydrobiol Special Issue: Advances in Limnology 51: 105-114

Kang CK, Lee YW, Choy EJ, Shin JK, Seo IS, Hong JS (2006) Microphytobenthos seasonality determines growth and reproduction in intertidal bivalves. Mar Ecol Prog Ser 315: $113-127$

> Kingston MB (2002) Effect of subsurface nutrient supplies on the vertical migration of Euglena proxima (Euglenophyta). J Phycol 38:872-880

Kühl M, Jørgensen BB (1994) The light field of microbenthic communities: radiance distribution and microscale optics of sandy coastal sediments. Limnol Oceanogr 39:1368-1398

> Kuwae T, Kibe E, Nakamura Y (2003) Effect of emersion and immersion on the porewater nutrient dynamics of an intertidal sandflat in Tokyo Bay. Estuar Coast Shelf Sci 57: 929-940

Leynaert A, Ní Longphuirt S, Claquin P, Chauvaud L, Ragueneau L (2009) No limit: the multiphasic uptake of silicic acid by benthic diatoms. Limnol Oceanogr (in press)

L'Helguen S, Madec C, Le Corre P (1996) Nitrogen uptake in permanently well-mixed temperate coastal waters. Estuar Coast Shelf Sci 42:803-818

Lomas MW, Glibert PM (1999a) Interactions between $\mathrm{NH}_{4}{ }^{+}$ and $\mathrm{NO}_{3}{ }^{-}$uptake and assimilation: comparison of diatoms and dinoflagellates at several growth temperatures. Mar Biol 133:541-551

Lomas MW, Glibert PM (1999b) Temperature regulation of nitrate uptake: a novel hypothesis about nitrate uptake and reduction in cool water diatoms. Limnol Oceanogr 44: $556-572$

> Lomas MW, Glibert PM (2000) Comparisons of nitrate uptake, storage, and reduction in marine diatoms and dinoflagellates. J Phycol 36:903-913

Lucas CH, Widdows J, Brinsley MD, Salkeld PN, Herman PMJ (2000) Benthic-pelagic exchange of microalgae at a tidal flat. 1. Pigment analysis. Mar Ecol Prog Ser 196: 59-73

> McCarthy JJ, Yilmaz A, Coban-Yildiz Y, Nevins JL (2007) Nitrogen cycling in the offshore waters of the Black Sea. Estuar Coast Shelf Sci 74:493-514

> Ní Longphuirt S, Leynaert A, Guarini JM, Chauvaud L and 
others (2006) Discovery of microphytobenthos migration in the subtidal zone. Mar Ecol Prog Ser 328:143-154

Palmer JD, Round FE (1965) Persistent, vertical-migration rhythms in benthic microflora. I. The effect of light and temperature on the rhythmic behaviour of Euglena obtusa. J Mar Biol Assoc UK 45:567-582

Raimbault P, Slawyk G, Boudjellal B, Coatanoan C and others (1999) Carbon and nitrogen uptake and export in the equatorial Pacific at $150^{\circ} \mathrm{W}$ : evidence of an efficient regenerated production cycle. J Geophys Res 104:3341-3356

Risgaard-Petersen N (2003) Coupled nitrification-denitrification in autotrophic and heterotrophic estuarine sediments: on the influence of benthic microalgae. Limnol Oceanogr 48:93-105

Risgaard-Petersen N, Nicolaisen $\mathrm{MH}$, Revsbech NP, Lomstein BA (2004) Competition between ammonium-oxidising bacteria and benthic microalgae. Appl Environ Microbiol 70:5528-5537

Robson BJ, Hamilton DP, Webster IT, Chan T (2008) Ten steps applied to development and evaluation of process-based biogeochemical models of estuaries. Environ Model Softw 23:369-384

Sakamaki T, Nishimura O, Sudo R (2006) Tidal time-scale variation in nutrient flux across the sediment-water interface of an estuarine tidal flat. Estuar Coast Shelf Sci 67: 653-663

Seeberg-Elverfeldt J, Schlüter M, Feseker T, Kölling M (2005) Rhizon sampling of porewaters near the sediment-water interface of aquatic systems. Limnol Oceanogr Methods 3: 361-371

Serôdio J, Catarino F (2000) Modeling the primary productivity of intertidal microphytobenthos: time scales of variability and effects of migratory rhythms. Mar Ecol Prog Ser 192:13-30

Shiomoto A, Sasaki K, Shiomoda T, Matsumura S (1994) Kinetics of nitrate and ammonium uptake by the natural populations of marine phytoplankton in the surface water of the Oyashio region during spring and summer. J Oceanogr 50:515-529

Strickland JDH, Parsons TR (1968) A practical handbook of

Editorial responsibility: Rodney Forster,

Lowestoft, UK seawater analysis. Bull Fish Res Board Can 167:49-80

Sundbäck K, Miles A (2000) Balance between denitrification and microalgal incorporation of nitrogen in microtidal sediments, NE Kattegat. Aquat Microb Ecol 22:291-300

Sundbäck K, Enoksson V, Granéli W, Pettersson K (1991) Influence of sublittoral microphytobenthos on the oxygen and nutrient flux between sediment and water: a laboratory continuous-flow study. Mar Ecol Prog Ser 74:263-279

Syrett PJ, Morris I (1963) The inhibition of nitrate assimilation by ammonium in Chlorella. Biochim Biophys Acta 67: 566-575

> Thornton DCO, Underwood GJC, Nedwell BD (1999) Effect of illumination and emersion period on the exchange of ammonium across the estuarine sediment-water interface. Mar Ecol Prog Ser 184:11-20

- Thornton DCO, Dong LF, Underwood GJC, Nedwell DB (2007) Sediment-water inorganic nutrient exchange and nitrogen budgets in the Colne Estuary, UK. Mar Ecol Prog Ser 337:63-77

Underwood GJC, Kromkamp J (1999) Primary production by phytoplankton and microphytobenthos in estuaries. Adv Ecol Res 29:93-153

Underwood GJC, Perkins RG, Consalvey MC, Hanlon ARM, Oxborough K, Baker NR, Paterson DM (2005) Patterns in microphytobenthic primary productivity: species-specific variation in migratory rhythms and photosynthetic efficiency in mixed-species biofilms. Limnol Oceanogr 50: 755-767

> Usui T, Koike I, Ogura N (1998) Tidal effect on dynamics of pore water nitrate in intertidal sediment of a eutrophic estuary. J Oceanogr 54:205-216

Wheeler PA, Glibert P, McCarthy JJ (1982) Ammonium uptake and incorporation by Chesapeake Bay phytoplankton: short term uptake kinetics. Limnol Oceanogr 27: $1113-1128$

Wilkinson GN (1961) Statistical estimations in enzyme kinetics. Biochem J 80:324-332

Wiltshire KH, Blakburn J, Paterson DM (1997) The cryolander: a new method for fine-scale in situ sampling of intertidal surface sediments. J Sediment Res 67:977-981

Submitted: February 29, 2008; Accepted: November 21, 2008 Proofs received from author(s): March 9, 2009 